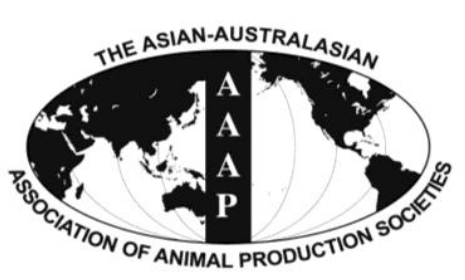

Open Access

Asian Australas. J. Anim. Sci.

Vol. 27, No. 1 : 115-122 January 2014

http://dx.doi.org/10.5713/ajas.2013.13284

www.ajas.info

pISSN 1011-2367 elSSN 1976-5517

\title{
Effect of Mechanically Deboned Chicken Meat Hydrolysates on the Physicochemical Properties of Imitation Fish Paste
}

\author{
Sang-Keun Jin ${ }^{\text {a }}$ Gwang-woong Go ${ }^{1, a}$, Eun-Young Jung ${ }^{2}$, Hyun-Jung Lim ${ }^{2}$, Han-Sul Yang ${ }^{3, *}$, and Jae-Hong Park ${ }^{4}$ \\ Department of Animal Resources Technology, Gyeongnam National University of Science and Technology, \\ Jinju, Gyeongnam 660-758, Korea
}

\begin{abstract}
This study investigated on the effects of adding mechanically deboned chicken meat (MDCM) hydrolysates on the quality properties of imitation fish paste (IFP) during storage. IFP was prepared from Alaska Pollack, spent laying hens surimi and protein hydrolysates which were enzymatically extracted from MDCM. The study was designed as a $3 \times 4$ factorial design with three MDCM hydrolysate content groups $(0 \%, 0.4 \%$, and $0.8 \%)$ and four storage times $(0,2,4$, and 6 weeks). Addition of MDCM hydrolysates increased crude fat content but lowered water content ( $\mathrm{p}<0.05)$. The breaking force of IFP, an indicator of gel formation, increased in treated groups compared to control $(\mathrm{p}<0.05)$. Angiotensin I-converting enzyme (ACE) activity was inhibited and free radical scavenging activity increased with increasing MDCM hydrolysate content ( $\mathrm{p}<0.05)$. In conclusion, the addition of MDCM to IFP improves gel characteristics. Additionally, protein hydrolysates from MDCM serve as a potential source of ACE inhibiting peptides. (Key Words: Surimi, Imitation Fish Paste, Mechanically Deboned Chicken Meat Hydrolysates, Gel Properties, Lipid Oxidation)
\end{abstract}

\section{INTRODUCTION}

Surimi, a stabilized myofibrillar protein from fish, is the primary ingredient in fish paste or imitation crab. It is prepared by separation, washing, and mincing to eliminate undesirable blood, lipids, enzymes, and sarcoplasmic proteins (Vilhelmsson, 1997; Park and Morrissey, 2000). In general, surimi is light in color, bland in odor, low in fat, and extremely functional due to the unique gelling

\footnotetext{
* Corresponding Author: Han-Sul Yang. Tel: +82-55-772-1948, Fax: +82-55-772-1949, E-mail: hsyang@gnu.kr

${ }^{1}$ The Department of Internal Medicine, Yale University School of Medicine, New Haven, CT 06510, USA.

${ }^{2}$ Division of Applied Life Science, Graduate School, Gyeongsang National University, Jinju, Gyeongnam 660-701, Korea.

${ }^{3}$ Department of Animal Science - Institute of Agriculture and Life Science, Gyeongsang National University, Jinju, Gyeongnam 660-701, Korea.

${ }^{4}$ Swine Science and Technology Center, Gyeongnam National University of Science and Technology, Jinju, Gyeongnam 660758 , Korea.

${ }^{\mathrm{a}}$ These authors equally contributed.

Submitted May 22, 2013; Accepted Sept. 25, 2013; Revised Oct. 9, 2013
}

properties of the myofibrillar proteins. These properties make surimi a robust functional ingredient for fabricating new food products (Han-Ching and Leinot, 1993; Lanier, 2000). Numerous studies have been conducted on surimi containing fish meat. In addition, application of surimi technology in the production of surimi-based products using the proteins from other animal species could provide a new approach for increasing its utilization and functional properties.

Animal meat is of much interest in the development of surimi-based products such as those made from beef, pork and chicken (Park et al., 1996; Srinivasan and Xiong, 1996; Kristinsson and Hultin, 2003). Pork leg meat, for instance, has been reported to have high myofibrillar protein content allowing increased gel forming capacity in surimi. Thus chicken or pork meat is an attractive substitute for fish meat surimi (Jin et al., 2007), with spent laying hens providing a particularly economical source of surimi-based products. Indeed, it was recently shown that spent laying hen meat has potential as filler in surimi-based products (Hur et al., 2011). Therefore, the addition of myofibrillar proteins from spent laying hens to surimi-based imitation fish paste (IFP) 
holds promise in promoting the utilization of such products.

It is important for the meat industry to develop new products to satisfy emerging consumer demands for high quality foods. Protein hydrolysates, rich in low molecular weight peptides (di- and tri-peptides, with minimal free amino acids), are a good dietary source due to their high nutritional value and therapeutic properties (Bhaskar et al., 2007). In recent years, research has focused on the generation of bioactive peptides from food sources including meat and meat by-products (Daoud et al., 2005; Li et al., 2007). Peptides have been shown to exert antioxidant, antimicrobial, and antihypertensive effects (Saiga et al., 2003a; Jang et al., 2008; Liu et al., 2009; Escudero et al., 2010). Some peptides possess antihypertensive activity through their ability to inhibit Angiotensin I-converting enzyme (ACE) (Arihara et al., 2001). Also, bioactive peptides can be used as components in functional foods. Protein hydrolysates have been shown to enhance the emulsifying and foaming properties of fish (Shahidi et al., 1995). These peptides need first to be released from the original protein during food processing or digestion in order to exhibit biological activity and little is known about this process in meat and meat products.

Mechanically deboned chicken meat (MDCM) has a high content of heme pigments, connective tissue, and fat (Yang and Froning, 1992). It is dark in color, has undesired textural properties, and is susceptible to lipid oxidation. However, MDCM is one of the most common raw materials used to produce processed poultry products. Also, MDCM is widely used in the food industry for upgrading the functional and nutritional properties of proteins, thereby creating value-added products. Thus, MDCM hydrolysis may be used as a potential starting material for the generation of bioactive peptides.

The aims of the present investigation were to study the effects of added MDCM hydrolysates on the gel properties, oxidative stability, and angiotensin I-converting enzymes (ACE) inhibitory activities of IFP made from Alaska Pollack and spend laying hen meat.

\section{MATERIALS AMD METHODS}

\section{Sample preparation}

Frozen Alaska Pollack were purchased from Han-sung Food Co. Ltd. (Pusan, Korea), cut into $500 \mathrm{~g}$ blocks while frozen, packed into polyethylene bags, and stored at $-20^{\circ} \mathrm{C}$ until use. Spent laying hens also were obtained at the same time from a commercial slaughterhouse. Spent laying hen myofibrillar protein was collected by the $\mathrm{pH}$ adjustment (Jin et al., 2008). MDCM hydrolysates were obtained by the protein hydrolysates method. Three batches were collected on different days for experimental replication. IFP samples were divided into three groups: Control (C); composed of
Table 1.The basic formulation of imitation fish paste

\begin{tabular}{lccc}
\hline Ingredients (\%) & Control & T1 & T2 \\
\hline Alaska Pollack & 59.70 & 59.70 & 59.70 \\
Spent laying hen surimi & 14.93 & 14.93 & 14.93 \\
Fresh egg white & 4.72 & 4.72 & 4.72 \\
Soy protein & 0.94 & 0.94 & 0.94 \\
Sugar & 1.51 & 1.51 & 1.51 \\
Salt & 1.51 & 1.51 & 1.51 \\
Monosodium glutamate & 1.26 & 1.26 & 1.26 \\
Seasoning mix & 0.31 & 0.31 & 0.31 \\
Wheat starch & 6.30 & 6.30 & 6.30 \\
Distilled water & 8.82 & 8.42 & 8.02 \\
MDCM ${ }^{1}$ hydrolysates & - & 0.4 & 0.8 \\
Total & 100 & 100 & 100 \\
\hline
\end{tabular}

${ }^{1}$ Mechanically deboned chicken meat.

commercial IFP containing spent laying hen meat, T1; consisted of IFP sample containing $0.4 \%$ MDCM hydrolysate, and T2; consisted of IFP sample containing $0.8 \%$ MDCM hydrolysate. The composition of the IFP is presented in Table 1 and a flow diagram depicting IFP preparation is shown in Figure 1.

pH method: The external fat tissue, bone, and skin were removed from the muscles, and the lean muscle was cut into approximately $3.0 \times 3.0 \times 2.0 \mathrm{~cm}^{3}$ cubes and ground through a

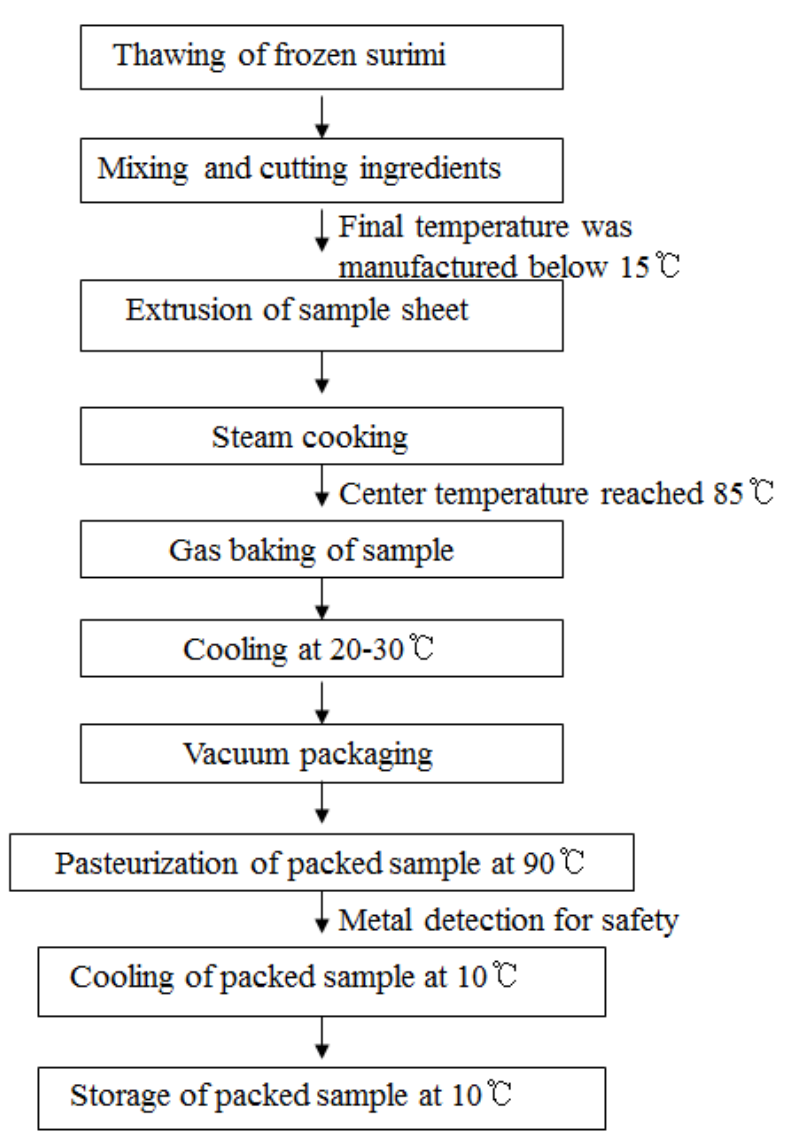

Figure 1. Manufacturing process of imitation fish paste. 
$3 \mathrm{~mm}$ diameter hole using a mincer. The minced samples were combined with six times volume of distilled water and homogenized with a Polytron homogenizer (T25-B, IKA Sdn. Bhd., Malaysia) at $8,000 \mathrm{rpm}$ for $30 \mathrm{~s}$. The $\mathrm{pH}$ of the homogenate was then adjusted to $\mathrm{pH} 11.0$ by the addition of $1 \mathrm{~mol} \mathrm{NaOH}$ and centrifuged at $10,000 \times g$ for $25 \mathrm{~min}$, after which the top layer of fat and bottom layer of connective tissue were discarded. The middle layer containing the myofibrillar protein was then adjusted to $\mathrm{pH} 5$ by addition of $1 \mathrm{~N} \mathrm{HCl}$ solution, after which it was centrifuged at $10,000 \times g$ for $25 \mathrm{~min}$. The resulting sediment was then used for the manufacture of IFP.

Preparation of the protein hydrolysates: In this study, one- and two-stage hydrolysis was employed. The nerves, skin, and visible fat were removed from the meat, which was then fragmented, ground, and homogenized with distilled water (meat:water ratio, 1:3 w/w). The homogenate was heated at $43^{\circ} \mathrm{C}$ and the $\mathrm{pH}$ was adjusted to 7.0 with $2 \mathrm{~N}$ $\mathrm{NaOH}$. Five percent of Protarmex) was added and the reaction $\mathrm{pH}$ was maintained at a constant $\mathrm{pH}$ by the addition of $2 \mathrm{~N} \mathrm{NaOH}$. The hydrolytic process was terminated by heating the mixture at $85^{\circ} \mathrm{C}$ for $20 \mathrm{~min}$, ensuring inactivation of the enzyme. The resulting slurry was centrifuged (Union 5KR, Hanil, Gangneung, Korea) at $8,000 \mathrm{rpm}$ for $10 \mathrm{~min}$ to remove insoluble fractions. The hydrolysate slurry was then heated to $50^{\circ} \mathrm{C}$ and the $\mathrm{pH}$ was adjusted to 7.0 with $2 \mathrm{~N} \mathrm{NaOH}$. Bromelain (1\%) was added to the mixture and the reaction $\mathrm{pH}$ was maintained by the addition of $2 \mathrm{~N} \mathrm{NaOH}$. After heating at $90^{\circ} \mathrm{C}$ for $15 \mathrm{~min}$ to inactivate the enzyme, the hydrolysate was centrifuged at $8,000 \mathrm{rpm}$ for $20 \mathrm{~min}$ to remove insoluble fractions. The degree of hydrolysis (DH) was determined using the $20 \%$ (w/v) trichloroactic acid (TCA) method, as described in the semi-micro Kjeldahl procedure. DH was defined as the percentage ratio of the total nitrogen in two-stage hydrolysate (A) to the total nitrogen in one-stage hydrolysate $(\mathrm{B})$, and calculated as $([\mathrm{A}-\mathrm{B}] / \mathrm{B}) \times 100(4.36 \%$ crude protein and $24.7 \% \mathrm{DH})$. The protein hydrolysate was then stored at $4{ }^{\circ} \mathrm{C}$ until use.

\section{Proximate composition}

The proximate composition analysis of IFP batters including moisture, crude protein, crude fat, and crude ash, was performed according to AOAC methods 950.46, 992.15, 985.15, and 920.153 for sausage batter (AOAC, 2000). Moisture, protein, fat, and ash parameters were determined in triplicate from IFP product.

\section{Gel characteristics}

The gel characteristics of cooked IFP samples were determined according to the method described by Phatcharat et al. (2006). Three cylindrical pieces $3.5 \mathrm{~cm}$ wide and $3 \mathrm{~cm}$ thick were maintained at $20^{\circ} \mathrm{C}$ prior to measuring. The breaking force, deformation, gel strength and jelly strength were measured using a texture analyzer (EZ-test, Shimadzu, Tokyo, Japan) equipped with a cylindrical plunger (diameter $5 \mathrm{~mm}$, depression speed 80 $\mathrm{mm} / \mathrm{min})$.

\section{Water-holding capacity (WHC)}

The water-holding capacity of IFP samples was determined by the method described by Hughes et al. (1997). Samples (approximately $10 \mathrm{~g}$ ) were placed in 50 $\mathrm{mL}$ plastic centrifuge tubes and heated for $15 \mathrm{~min}$ in a water bath $\left(90^{\circ} \mathrm{C}\right)$. The samples were then cooled to room temperature and centrifuged at $9,000 \times g$ at $4^{\circ} \mathrm{C}$ for $20 \mathrm{~min}$ (Union 5KR, Hanil, Korea). The supernatant was eliminated and the WHC of the remaining pellets were calculated as follows: WHC $(\%)=1-([$ weight of sample before heatingweight of sample after heating and centrifugation]/total water content in the samplex100).

\section{2,2-diphenyl-1-picryhydrazla hydrate (DPPH) radical scavenging activity}

The DPPH radical scavenging activity measurement was modified according to the method of Bersuder et al. (1998). $500 \mu \mathrm{L}$ of each peptide fraction was mixed with $500 \mu \mathrm{L}$ of ethanol and $250 \mu \mathrm{L}$ of a DPPH solution $(0.5 \mathrm{mM} 1,1$ diphenyl-2-picrylhydrazyl/ethanol). The mixtures were incubated for $30 \mathrm{~min}$ in the dark at room temperature and the reduction of DPPH radicals was measured at $517 \mathrm{~nm}$. DPPH radical scavenging activity was calculated as: DPPH radical scavenging activity $(\%)=([$ absorption of controlabsorption of sample]/absorption of control $) \times 100$. The control was conducted in the same manner, with the exception that distilled water was used instead of sample.

\section{Lipid oxidation}

Lipid oxidation was determined using the thiobarbituric acid reactive substances (TBARS) method (Buege and Aust, 1978). Cooked IFP sample ( $5 \mathrm{~g}$ ) was weighed into a $50 \mathrm{~mL}$ test tube and homogenized with $15 \mathrm{~mL}$ of deionized distilled water using the Polytron homogenizer for $15 \mathrm{~s}$ at the highest speed (T25basic, IKA, Selangor, Malaysia). The IFP sample homogenate $(2 \mathrm{~mL})$ was transferred to a disposable test tube $(13 \times 100 \mathrm{~mm})$ and butylated hydroxyanisole $(10 \%, 50 \mu \mathrm{L})$ and thiobarbituric acid/trichloroacetic acid (TBA/TCA) solutions (4 mL) were added. The sample was mixed using a vortex mixer, incubated in a boiling water bath for 15 min to allow color development, and cooled at room temperature. Absorbance was determined at $531 \mathrm{~nm}$ against a blank containing $2 \mathrm{~mL}$ of deionized distilled water and $4 \mathrm{~mL}$ of TBA/TCA solution. The TBARS measure was expressed in $\mathrm{mg}$ of malondialdehyde (MDA) per $\mathrm{kg}$ of sample. 


\section{Angiotensin I-converting enzyme (ACE) inhibitory activity}

ACE activity assay: The activity of ACE was determined using hippuryl-His-Leu (HHL) with the methods reported by Janitha et al. (2002). The assay was conducted in a Borate buffer $(0.1 \mathrm{M}, \mathrm{pH} 8.3)$. The assay volume consisted of $150 \mu \mathrm{L}$ of the ACE enzyme solution and $40 \mu \mathrm{L}$ of assay sample. All of the solutions were incubated for $10 \mathrm{~min}$ at $37^{\circ} \mathrm{C} .5 \mathrm{~mL}$ of $\mathrm{HHL}(0.3 \mathrm{M})$ and $100 \mu \mathrm{L}$ of $0.1 \mathrm{M}$ Borate buffer ( $\mathrm{pH} 8.3$ ) were added and incubated for $30 \mathrm{~min} .1 \mathrm{M} \mathrm{HCl}(150 \mu \mathrm{L})$ was added to stop ACE activity. The reaction mixture obtained was used to quantitate the hippuric acid produced due to ACE activity on the substrate.

HPLC determination of hippuric acid content: A reversed-phase $\mathrm{C}_{18}$ column (Bonclone $\mathrm{C}_{18}, 10 \mu \mathrm{M}, 50 \times 1.0$ $\mathrm{mm}$ ) protected by a guard column (Bondclone $\mathrm{C}_{18}, 5 \mu \mathrm{M}$, $250 \times 4.6 \mathrm{~mm}$, Phenomenex Co., Torrance, CA, USA) was employed. The injection volume used was $20 \mu \mathrm{L}$. Elution of hippuric acid was detected by monitoring the absorbance at $228 \mathrm{~nm}$. The control reaction mixture contained $40 \mu \mathrm{L}$ of buffer instead of the assay sample. The percent inhibition of enzyme activity was calculated as follows: ACE inhibition $(\%)=([$ hippuric acid of control-hippuric acid of sample] /hippuric acid of control) $\times 100$. The concentration of hydrolysate needed to inhibit $50 \%$ of ACE activity was defined as the $\mathrm{IC}_{50}$ value.

\section{Statistical analysis}

The study was designed as a $3 \times 4$ factorial experiment with treatment (control, T1 and T2) and storage time $(0,2,4$, and 6 weeks). The experiment was replicated three times. Data were analyzed using the general linear model (GLM) (SAS, 2000). Duncan's multiple test was used to determine the statistical significance among the means at a $95 \%$ significance level.

\section{RESULTS AND DISCUSSION}

\section{Proximate composition}

The proximate composition of IFP with added MDCM hydrolysates is shown in Table 2. In this study, the IFP showed no significant difference in crude protein compared to the control during storage. However, all treatments with MDCM hydrolysates had lower moisture content compared to control at 0 and 6 weeks storage periods $(\mathrm{p}<0.05)$. Crude fat content in the MDCM hydrolysate-added groups was significantly higher than in the control at week 0 of storage. Likewise, the ash content in the $0.8 \%$ MDCM hydrolysateadded sample was significantly lower than in the other groups at 6 weeks of storage $(p<0.05)$. The functional and textural properties of surimi depend on many factors
Table 2. Proximate composition of imitation fish paste batter with added MDCM hydrolysates

\begin{tabular}{llcc}
\hline Treatments $^{1}$ & & \multicolumn{2}{c}{ Storage periods (weeks) } \\
\cline { 3 - 4 }$(\mathrm{g} / 100 \mathrm{~g})$ & & 0 & 6 \\
\hline Moisture & $\mathrm{C}$ & $69.74 \pm 0.10^{\mathrm{Aa}}$ & $69.22 \pm 0.11^{\mathrm{Ab}}$ \\
& $\mathrm{T} 1$ & $68.87 \pm 0.12^{\mathrm{B}}$ & $68.67 \pm 0.30^{\mathrm{B}}$ \\
& $\mathrm{T} 2$ & $69.00 \pm 0.10^{\mathrm{B}}$ & $68.73 \pm 0.17^{\mathrm{B}}$ \\
Crude protein & $\mathrm{C}$ & $18.16 \pm 0.17$ & $18.82 \pm 0.32$ \\
& $\mathrm{~T} 1$ & $18.39 \pm 0.52$ & $18.72 \pm 0.54$ \\
& $\mathrm{~T} 2$ & $17.28 \pm 0.18^{\mathrm{b}}$ & $18.02 \pm 0.08^{\mathrm{a}}$ \\
Crude fat & $\mathrm{C}$ & $0.80 \pm 0.02^{\mathrm{Bb}}$ & $1.20 \pm 0.01^{\mathrm{a}}$ \\
& $\mathrm{T} 1$ & $1.02 \pm 0.06^{\mathrm{A}}$ & $1.10 \pm 0.20$ \\
& $\mathrm{~T} 2$ & $1.07 \pm 0.09^{\mathrm{A}}$ & $1.15 \pm 0.05$ \\
Ash & $\mathrm{C}$ & $0.76 \pm 0.13$ & $0.71 \pm 0.03^{\mathrm{A}}$ \\
& $\mathrm{T} 1$ & $0.87 \pm 0.17$ & $0.73 \pm 0.01^{\mathrm{A}}$ \\
& $\mathrm{T} 2$ & $0.75 \pm 0.12^{\mathrm{a}}$ & $0.49 \pm 0.01^{\mathrm{Bb}}$ \\
\hline
\end{tabular}

Data are means \pm standard deviation. $n=3$.

${ }_{\mathrm{A}, \mathrm{B}}$ Means with different superscript capital letters in a column within each treatment differ significantly $(\mathrm{p}<0.05)$.

${ }^{a, b}$ Means with different superscript small letters in a row within each storage time differ significantly $(\mathrm{p}<0.05)$.

${ }^{1}$ Treatments are the same as in Table 1.

including thermal conditions and various gelling and nongelling ingredients (Nowasd et al., 2000). In general, high protein, low fat, and adequate water are required to make high quality surimi-based products (Jin et al., 2007), Moisture and fat are critical factors in surimi products (Uddin et al., 2006) and excessive lipids may adversely affect quality, due to oxidized lipids interacting with proteins (Smith, 1987). Also, protein concentration greatly affects the gel properties (Luo et al., 2004). However, we assumed that the protein contents would not influence the physical properties of IFP in this study because protein showed no consistent trends among the samples.

\section{Gel characteristics}

Gel characteristics of IFP with added MDCM hydrolysates are shown in Table 3 . The breaking force values increased during storage in $\mathrm{T} 1$ and $\mathrm{T} 2$. The breaking force was lower in $\mathrm{T} 2$ as compared to T1 until 2 weeks storage $(\mathrm{p}<0.05)$. The gel strength and jelly strength showed consistent trends among the IFP samples; however, treatment with MDCM hydrolysates imparted higher breaking force values than control group at 4 and 6 weeks. Also, deformation, gel strength, and jelly strength were improved with added MDCM compared to the control group at 4 or 6 weeks $(\mathrm{p}<0.05)$. Protein concentration has a major positive effect on the breaking force (Luo et al., 2008). It has also been reported (Sylvia et al., 1994) that the gel-forming ability of surimi increases with decreasing water content, a result of higher myofibril protein concentrations and increased cross-link density. Therefore, 
Table 3. Changes in gel characteristics in imitation fish paste with added MDCM hydrolysates during cold storage

\begin{tabular}{llcccc}
\hline Treatments $^{1}$ & & \multicolumn{4}{c}{ Storage periods (weeks) } \\
\cline { 2 - 5 } Breaking force & $\mathrm{C}$ & $379.67 \pm 7.51^{\mathrm{A}}$ & $408.00 \pm 20.07^{\mathrm{A}}$ & $382.33 \pm 20.53^{\mathrm{B}}$ & $357.00 \pm 26.46^{\mathrm{B}}$ \\
(g) & $\mathrm{T} 1$ & $374.67 \pm 6.43^{\mathrm{Ac}}$ & $394.74 \pm 10.74^{\mathrm{Abc}}$ & $435.33 \pm 24.66^{\mathrm{Aa}}$ & $417.00 \pm 10.00^{\mathrm{Aab}}$ \\
& $\mathrm{T} 2$ & $341.33 \pm 16.77^{\mathrm{Bc}}$ & $355.00 \pm 8.66^{\mathrm{Bc}}$ & $433.33 \pm 12.58^{\mathrm{Aa}}$ & $398.0 \pm 3.61^{\mathrm{Ab}}$ \\
Deformation & $\mathrm{C}$ & $6.91 \pm 0.21^{\mathrm{a}}$ & $6.71 \pm 0.06^{\mathrm{a}}$ & $5.81 \pm 0.32^{\mathrm{Cb}}$ & $5.71 \pm 0.21^{\mathrm{Bb}}$ \\
$(\mathrm{mm})$ & $\mathrm{T} 1$ & $6.67 \pm 0.25$ & $6.47 \pm 0.35$ & $6.31 \pm 0.12^{\mathrm{B}}$ & $6.61 \pm 0.35^{\mathrm{A}}$ \\
& $\mathrm{T} 2$ & $6.71 \pm 0.21$ & $6.51 \pm 0.15$ & $6.91 \pm 0.23^{\mathrm{A}}$ & $6.77 \pm 0.15^{\mathrm{A}}$ \\
Gel strength & $\mathrm{C}$ & $262.32 \pm 12.96^{\mathrm{Aa}}$ & $273.70 \pm 15.58^{\mathrm{a}}$ & $231.43 \pm 37.19^{\mathrm{Bab}}$ & $203.36 \pm 7.96^{\mathrm{Bb}}$ \\
(g/cm $\left.{ }^{2}\right)$ & $\mathrm{T} 1$ & $249.93 \pm 5.95^{\mathrm{AB}}$ & $262.79 \pm 25.52$ & $274.63 \pm 18.13^{\mathrm{AB}}$ & $275.63 \pm 18.99^{\mathrm{A}}$ \\
& $\mathrm{T} 2$ & $228.97 \pm 14.58^{\mathrm{Bc}}$ & $231.00 \pm 8.49^{\mathrm{c}}$ & $299.27 \pm 12.61^{\mathrm{Aa}}$ & $269.56 \pm 5.40^{\mathrm{Ab}}$ \\
Jelly strength & $\mathrm{C}$ & $193.62 \pm 3.82^{\mathrm{A}}$ & $207.92 \pm 10.22^{\mathrm{A}}$ & $202.60 \pm 23.43$ & $181.18 \pm 13.47^{\mathrm{B}}$ \\
$(\mathrm{g} / \mathrm{mm})$ & $\mathrm{T} 1$ & $190.16 \pm 3.27^{\mathrm{Ab}}$ & $206.34 \pm 8.94^{\mathrm{Aa}}$ & $221.13 \pm 12.56^{\mathrm{a}}$ & $212.76 \pm 5.09^{\mathrm{Aa}}$ \\
& $\mathrm{T} 2$ & $173.39 \pm 8.54^{\mathrm{Bc}}$ & $180.00 \pm 4.41^{\mathrm{Bc}}$ & $220.94 \pm 6.40^{\mathrm{a}}$ & $202.99 \pm 1.83^{\mathrm{Ab}}$ \\
\hline
\end{tabular}

Data are means \pm standard deviation. $n=3$.

A-C Means with different superscript capital letters in a column within each treatment differ significantly $(\mathrm{p}<0.05)$.

${ }^{a-c}$ Means with different superscript small letters in a row within each storage time differ significantly $(p<0.05)$.

${ }^{1}$ Treatments are the same as in Table 1.

our results indicate that the gel characteristics are favorably influenced by changes of proximate compositions and the addition of MDCM to IFP.

Water holding capacity (WHC), DPPH radical scavenging activity and lipid oxidation

Water holding capacity (WHC), DPPH radical scavenging activity, and lipid oxidation of IFP with added MDCM hydrolysates are shown in Table 4. The WHC was lower when MDCM hydrolysates were added compared to the control group during storage $(\mathrm{p}<0.05)$. During cooking, various meat proteins denature causing structural changes, shrinkage of meat fibers, and gel formation of myofibrillar proteins (Tornberg, 2005). Therefore, our current results suggest that the addition of MDCM to IFP may not directly affect WHC, but that with extensive degradation of muscle fibers an apparent WHC reduction occurs.

All treatment samples demonstrated increased DPPH radical scavenging activity during storage, while IFP showed significantly decreased DPPH radical scavenging activity after 2 weeks $(\mathrm{p}<0.05)$. DPPH radical scavenging activity was higher in the MDCM hydrolysate treatment groups compared to the control up until 4 weeks. The free radical scavenging activity and antioxidant activity; including the ability to donate hydrogen, to stabilize or terminate radicals, to sequester pro-oxidative metal ions, and to form a physical barrier around fat droplets, is determined by a specific amino acid composition and sequence (Kong and Xiong, 2006). Additionally, hydrolysate antioxidant activity depends upon the enzyme used. It has been reported (Wu et al., 2003) that DPPH activity improved for mackerel protein hydrolysate

Table 4. Changes in water-holding capacity (WHC), DPPH radical scavenging activity and TBARS in imitation fish paste with added MDCM hydrolysates during cold storage

\begin{tabular}{llcccc}
\hline Treatments $^{1}$ & & \multicolumn{4}{c}{ Storage periods (weeks) } \\
\cline { 3 - 6 } & & 0 & 2 & 4 & 6 \\
\hline WHC & $\mathrm{C}$ & $69.74 \pm 0.10^{\mathrm{Aa}}$ & $69.40 \pm 0.10^{\mathrm{Ab}}$ & $69.71 \pm 0.02^{\mathrm{Aa}}$ & $69.22 \pm 0.11^{\mathrm{Ac}}$ \\
$(\%)$ & $\mathrm{T} 1$ & $68.82 \pm 0.12^{\mathrm{B}}$ & $69.05 \pm 0.09^{\mathrm{B}}$ & $68.97 \pm 0.12^{\mathrm{B}}$ & $68.67 \pm 0.30^{\mathrm{B}}$ \\
& $\mathrm{T} 2$ & $69.00 \pm 0.10^{\mathrm{B}}$ & $68.61 \pm 0.14^{\mathrm{C}}$ & $68.58 \pm 0.25^{\mathrm{C}}$ & $68.73 \pm 0.17^{\mathrm{B}}$ \\
DPPH & $\mathrm{C}$ & $19.70 \pm 1.00^{\mathrm{Cb}}$ & $21.76 \pm 1.66^{\mathrm{Ca}}$ & $17.63 \pm 1.21^{\mathrm{Bc}}$ & $13.91 \pm 1.16^{\mathrm{d}}$ \\
$(\%)$ & $\mathrm{T} 1$ & $21.20 \pm 0.46^{\mathrm{Bb}}$ & $23.69 \pm 1.69^{\mathrm{Ba}}$ & $19.00 \pm 1.29^{\mathrm{Ac}}$ & $14.15 \pm 1.11^{\mathrm{d}}$ \\
& $\mathrm{T} 2$ & $23.98 \pm 0.91^{\mathrm{Ab}}$ & $25.44 \pm 1.42^{\mathrm{Aa}}$ & $20.65 \pm 0.84^{\mathrm{Ac}}$ & $14.44 \pm 0.74^{\mathrm{d}}$ \\
TBARS & $\mathrm{C}$ & $0.51 \pm 0.03^{\mathrm{c}}$ & $2.27 \pm 0.01^{\mathrm{b}}$ & $2.62 \pm 0.06^{\mathrm{a}}$ & $2.49 \pm 0.09^{\mathrm{Cab}}$ \\
$(\mathrm{mg} / 100 \mathrm{~g})$ & $\mathrm{T} 1$ & $0.49 \pm 0.04^{\mathrm{c}}$ & $2.50 \pm 0.02^{\mathrm{b}}$ & $2.56 \pm 0.04^{\mathrm{ab}}$ & $2.62 \pm 0.04^{\mathrm{Ba}}$ \\
& $\mathrm{T} 2$ & $0.43 \pm 0.03^{\mathrm{d}}$ & $2.50 \pm 0.05^{\mathrm{c}}$ & $2.60 \pm 0.04^{\mathrm{b}}$ & $2.82 \pm 0.01^{\mathrm{Aa}}$ \\
\hline
\end{tabular}

Data are means \pm standard deviation. $n=3$.

${ }^{A-B}$ Means with different superscript capital letters in a column within each treatment differ significantly $(\mathrm{p}<0.05)$.

${ }^{a-c}$ Means with different superscript small letters in a row within each storage time differ significantly $(p<0.05)$.

${ }^{1}$ Treatments are the same as in Table 1. 


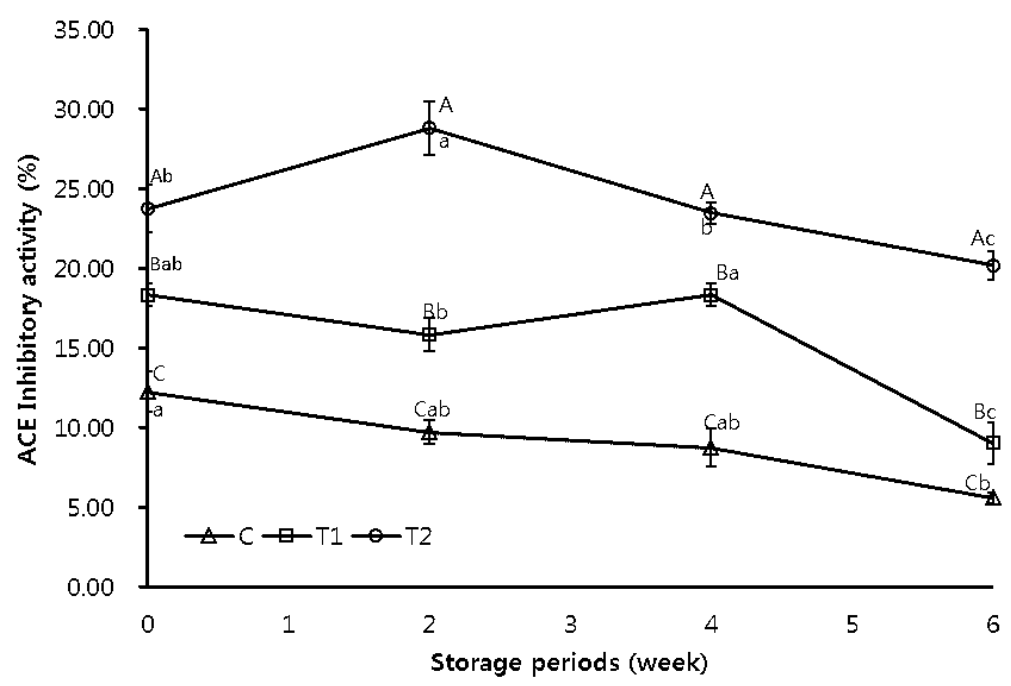

Figure 2. Changes in angiotensin I-converting enzyme (ACE) inhibitor activity (\%) in imitation fish paste with added MDCM hydrolysates. Data are means \pm standard deviation. $n=3{ }^{\text {A-C }}$ Means with different superscript capital letters within each treatment differ significantly $(\mathrm{p}<0.05)$. ${ }^{\mathrm{a}-\mathrm{c}}$ Means with different superscript small letters within each storage time differ significantly $(\mathrm{p}<0.05)$.

${ }^{1}$ Treatments are the same as in Table 1.

generated by Protease N. Another group (Wu et al., 2004) found that porcine hemoglobin hydrolysates, prepared through hydrolysis by Alcalase followed by Flavourzyme, exhibited high ferrous ion chelating abilities and DPPH radical scavenging activity. In our research, the DPPH radical scavenging activities of the Alcalase hydrolysates were similar to those reported by Wu et al. (2004).

The TBARS value increased in correlation with increasing storage periods in all IFP samples. In the treatment groups, TBARS values rapidly increased at 2 weeks $(\mathrm{p}<0.05)$ while they did not differ significantly among IFP samples until 4 weeks. TBARS values were higher in the MDCM hydrolysate treatment groups compared to the control at 6 weeks $(\mathrm{p}<0.05)$. Ahn et al. (1993) reported that differences in fat content, fatty acid composition, and the classes of lipids present effected the lipid oxidation of stored turkey patties. Meat products with a high degree of unsaturation are more susceptible to lipid oxidation (Morrissey et al., 1998). Accordingly, lipid oxidation in the present study was influenced by fat content (Table 2). Previously, Sakanaka and Tachibana (2006) reported reduction of TBARS values in beef homogenate by egg-yolk protein hydrolysates. However, hydrolysates possess a lower antioxidant activity in meatballs (Flaczyk et al., 2006). Hydrolysates at doses ranging from $1 \%$ to $2 \%$ slowed lipid oxidation of pork patties but their activity remained weaker than synthetic antioxidants (Pena-Ramos and Xiong, 2003).

\section{Angiotensin I-converting enzyme (ACE) inhibitory activity}

The ACE inhibitory activity in IFP with added MDCM hydrolysates is shown in Figure 2. ACE inhibitory activity of IFP showed a decreasing trend with increasing storage time. However, the ACE activity in the IFP with added treatments was lower than that of control. Addition of $0.8 \%$ MDCM hydrolysates was found to be more effective at inhibiting ACE activity of IFP compared to addition of $0.4 \%$ MDCM hydrolysates $(p<0.05)$. ACE inhibitory peptides have been discovered in various animal sources such as porcine and chicken muscle. Specific ACE inhibitory peptides, Met-Asn-Pro-Asn $\left(\mathrm{IC}_{50}=66.6 \mu \mathrm{M}\right)$, Asn-Pro-Pro $\left(\mathrm{IC}_{50}=290.5 \mu \mathrm{M}\right)$, and Thr-Asn-Pro $\left(\mathrm{IC}_{50}=\right.$ $207.4 \mu \mathrm{M})$ were discovered in a porcine myosin hydrolysate (Arihara et al., 2001). Gly-Phe-Hyp-Gly-Thr-Hyp-Gly-LeuHyp-Gly-Phe $\left(\mathrm{IC}_{50}=42 \mu \mathrm{M}\right)$ was isolated from chicken breast muscle hydrolysate (Saiga et al., 2003b). Ahhmed et al. (2009) reported that mixing 5\% meat hydrolysate from the porcine muscle biceps femoris with normal diet in rats resulted in clear positive effects on a common lifestylerelated disease such as hypertension. ACE plays an important role in the regulation of blood pressure as well as fluid and salt balance in mammals. Therefore, our results support the conclusion that MDCM hydrolysates can be used as a good source of health-promoting constituents in functional foods.

\section{ACKNOWLEDGEMENTS}

This work was supported by Technology Development Program for Ministry for Food, Agriculture, Forestry and Fisheries and the Priority Research Centers Program through the national research foundation of Korea (FRF) funded by the Ministry of Education, Science and 
Technology, Republic of Korea. Also, following are results of a study on the "Leaders in Industry-university Cooperation" project, supported by the Ministry of Education.

\section{REFERENCES}

Ahhmed, M. A., S. Kawahara, and M. Muguruma. 2009. Transglutaminate improves the textural and structural properties of chicken skeletal, smooth, and cardiac muscles. Proceeding of the $55^{\text {th }}$ International Congress of Meat Science and Technology. Copenhagen, Denmark.

Ahn, D. U., A. Ajuyah, F. H. Wolf, and J. S. Sim. 1993. Oxygen availability affects prooxidant catalyzed lipid oxidation of cooked turkey patties. J. Food Sci. 58:278-291.

AOAC. 2000. Official methods of analysis. 17th edn. Association of Official Analytical Chemists. Gaithersburg, MD.

Arihara, K., Y. Nakashima, T. Mukai, S. Ishikawa, and M. Itoh. 2001. Peptide inhibitors for angiotensin I-converting enzyme from enzymatic hydrolysates of porcine skeletal muscle proteins. Meat Sci. 57:319-324.

Bersuder, P., M. Hole, and G. Smith. 1998. Antioxidants from heated histidine-glucose model system. 1. Investigation of the antioxidant role of histidine and isolation of antioxidants by high performance liquid chromatography. J. Am. Oil Chem. Soc. 75:181-187.

Bhaskar, N., V. K. Modi, K. Govindaraju, C. Radha, and R. G. Lalitha. 2007. Utilization of meat industry by products: protein hydrolysate from sheep visceral mass. Bioresour. Technol. 98:388-394.

Buege, J. A. and S. D. Aust. 1978. Microsomal lipid peroxidation. Meth. Enzymol. 52:302-310.

Daoud, R., V. Dubios, L. Bors-Dodita, N. Nedjar-Arroume, F. Krier, and N. E. Chihib. 2005. New antibacterial peptide derived from bovine hemoglobin. Peptides 26:713-719.

Escudero, E., M. A. Sentandreu, K. Arihara, and F. Toldrá. 2010. Angiotensin I-converting enzyme inhibitory peptides generated from in vitro gastrointestinal digestion of pork meat. J. Agric. Food Chem. 58:2895-2901.

Flaczyk, E., M. Rudzinska, E. Wasowicz, J. Korczak, and R. Amarowicz. 2006. Effect of crackling hydrolysates on oxidative stability of pork meatballs fat. Food Res. Int. 39:924931.

Han-Ching, L. and A. Leinot. 1993. Surimi composition and technology: present status and nutritional consideration. Int. J. Food Sci. Nutr. 44(S1):S55-S63.

Hughes, E., S. Confrades, and D. J. Troy. 1997. Effects of fat level, oat fibre and carrageenan on frankfurters formulated with 5, 12 and 30\% fat. Meat Sci. 45:273-281.

Hur, S. J., B. D. Choi, Y. J. Choi, B. G. Kim, and S. K. Jin. 2011. Quality characteristics of imitation crab sticks made from Alaska Pollack and spent laying hen meat. LWT-Food Sci. Technol. 44:1482-1489.

Jang, A., C. Jo, K. S. Kang, and M. Lee. 2008. Antimicrobial and human cancer cell cytotoxic effect of synthetic angiotensinconverting enzyme (ACE) inhibitory peptides. Food Chem. 107:327-336

Janitha, P. K., P. D. Wanasundara, A. R. S. Rose, R. Amarowicz, S.
J. Ambrose, and R. B. Pegg. 2002. Peptides with angiotensin Iconverting enzyme (ACE) inhibitory activity from defibrinated, hydrolyzed bovine plasma. J. Agric. Food Chem. 50:69816988.

Jin, S. K., I. S. Kim, Y. J. Choi, G. B. Park, and H. S. Yang. 2008. Quality characteristics of chicken breast surimi as affected by water washing time and $\mathrm{pH}$ adjustment. Asian-Aust. J. Anim. Sci. 21:449-455.

Jin, S. K., I. S. Kim, S. J. Kim, K. J. Jeong, Y. J. Choi, and S. J. Hur. 2007. Effect of muscle type and washing times on physicchemical characteristics and qualities of surimi. J. Food Eng. 81:618-623.

Kong, B. H. and Y. L. Xiong. 2006. Antioxidant activity of zein hydrolysates in a liposome system and the possible mode of action. J. Agric. Food Chem. 54:6059-6068.

Kristinsson, H. G. and H. O. Hultin. 2003. Role of pH and ionic strength on water relationships in washed minced chicken breast muscle gels. J. Food Sci. 68:917-922.

Lanier, T. C. 2000. Surimi gelation chemistry. In: Surimi and surimi seafood (Ed. J. W. Park). New York. Marcel Dekker. pp. 237-265.

Li, B., F. Chen, X. Xang, B. Ji, and Y. Wu. 2007. Isolation and identification of antioxidative peptides from porcine collagen hydrolysate by conseutive chromatography and electrospray ionization-mass spectrometry. Food Chem. 102:1135-1143.

Liu, Q., B. Kong, L. Jiang, X. Cui, and J. Liu. 2009. Free radical scavenging activity of porcine plasma protein hydrolysates determined by electron spin resonance spectrometer. LWTFood Sci. Technol. 42:956-962.

Luo, Y., R. Kuwahara, M. Kaneniwa, Y. Murata, and M. Yokoyama. 2004. Effect of soy protein isolate on gel properties of Alaska Pollack and common carp surimi at different setting conditions. J. Sci. Food Agric. 84:663-671.

Luo, Y., H. Shen, D. Pan, and G. Bu. 2008. Gel properties of surimi from silver carp (Hypophthalmichthys molitrix) as affected by heat treatment and soy protein isolate. Food Hydrocoll. 22:1513-1519.

Morrissey, P. A., P. J. A. Sheehy, K. Galvin, and J. P. Kerry. 1998. Lipid stability in meat and meat products. Meat Sci. 49:73-86.

Nowasd, A. A. A. K. M., S. Kanoh, and E. Niwa. 2000. Thermal gelation characteristics of breast and thigh muscles of spend hen and broiler and their surimi. Meat Sci. 54:169-175.

Park, S., M. S. Brewer, J. Novakofski, P. J. Bechtel, and F. K. McKeith. 1996. Process and characteristics for a surimi-like material made from beef or pork. J. Food Sci. 61:422-427.

Park, J. W. and M. T. Morrissey. 2000. Manufacturing of surimi from light muscle fish. In: Surimi and surimi seafood (Ed. J. W. Park). New York. Marcel Dekker. pp. 23-58.

Pena-Ramos, E. A. and Y. L. Xiong. 2003. Whey and soy protein hydrolysates inhibit lipid oxidation in cooked pork patties. Meat Sci. 64:259-263.

Phatcharat, S., S. Benjakul, and W. Visessanguan. 2006. Effects of washing with oxidizing agents on the gel-forming ability and physicochemical properties of surimi produced from bigeye snapper. Food Chem. 98:431-439.

Saiga, A., S. Tananbe, and T. Nishimura. 2003a. Antioxidnat activity of peptides obtained from porcine myofibrillar proteins by protease treatment. J. Agric. Food Chem. 51:36613667. 
Saiga, A., T. Okumura, T. Makihara, S. Katsuta, T. Shinizu, R. Yamada, and T. Nishimura. 2003b. Angiotensin I-converting enzyme inhibitory peptides in a hydrolyzed chicken breast muscle extract. J. Agric. Food Chem. 51:1741-1745.

Sakanaka, S. and Y. Tachibana. 2006. Active oxygen scavenging activity of egg-yolk protein hydrolysates and their effects on lipid oxidation in beef and tuna homogenates. Food Chem. 95:243-249.

SAS Institute Inc. 2000. SAS/STAT user's guide: Version 8.2. Cary, NC.

Shahidi, F., X. Han, and J. Synowiecki. 1995. Production and characteristics of protein hydrolysates from capelin (Mallotus villosus). Food Chem. 53:285-293.

Smith, D. M. 1987. Functional and biochemical change in deboned turkey due to frozen storage and lipid oxidation. J. Food Sci. 52:22-27.

Srinivasan, S. and Y. L. Xiong. 1996. Gelation of beef heart surimi as affected by antioxidants. J. Food Sci. 61:707-711.

Sylvia, S. F., J. R. Claus, N. G. Mariott, and W. N. Eigel. 1994. Low-fat, high-moisture frankfurters: Effects of temperature and water during extended mixing. J. Food Sci. 59:937-940.
Tornberg, E. 2005. Effect of heat on meat proteins- Implications on structure and quality of meat products: A review. Meat Sci. 70:493-508.

Uddin, M., E. Okazaki, H. Fukushima, S. Turza, Y. Yumiko, and Y. Fukuda. 2006. Nondestructive determination of water and protein in surimi by near-infrared spectroscopy. Food Chem. 96:491-495.

Vilhelmsson, O. 1997. The state of enzyme biotechnology in the fish processing industry. Trends Food Sci. Technol. 8:266-270.

Wu, H. C., H. M. Chen, and C. Y. Shiau. 2003. Free amino acids and peptides as related to antioxidant properties in protein hydrolysates of mackerel (Scomber austriasicus). Food Res. Int. 36:949-957.

Wu, K. C., Z. Y. Lin, S. H. Chiang, and C. Y. Chang. 2004. Antioxidant properties of porcine blood proton before and after enzymatic hydrolysis. J. Biomass Energ. Soc. China. 23:79-85.

Yang, T. S. and G. W. Froning. 1992. Selected washing processes affect thermal gelation properties and microstructure of mechanically separated chicken meat. J. Food Sci. 57:325-329. 